\title{
Hepatitis B infection in Yemenis in Sana'a: pattern and risk factors
}

K.A. Al-Nassiri ${ }^{1}$ and Y.A. Raja'a²

$$
\begin{aligned}
& \text { عدوى التهاب الكبد البائي بين اليمنيين في صنعاء: غط العدارى وعوامل الالختطار } \\
& \text { نحالد أتمد النصيري وييحي أسمد رجائ }
\end{aligned}
$$

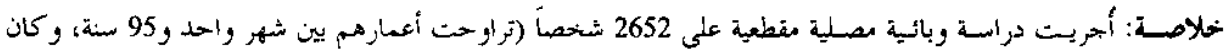

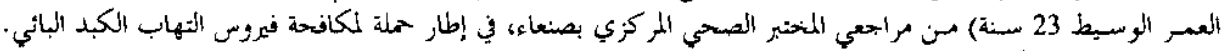

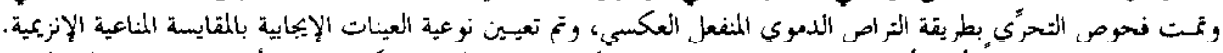

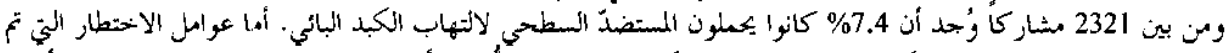

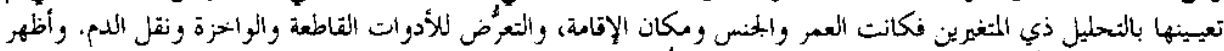

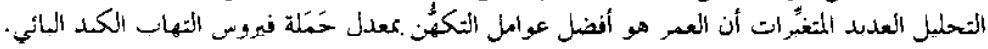

ABSTRACT A cross-sectional seroepidemiological study was conducted among 2652 individuals (age range: 1 month-95 years; median 23 years) who presented at Sana'a Central Health Laboralory in response to a campaign to control hopatitis 8 yirus. Serooning was carried out by reverse passive haemagglutination. Specificity of positive samples was determined by enzyme immunoassay. Of 2321 participants, $7.4 \%$ were carriers of hepatitis B surface antigen. Risk factors determined by bivariate analysis were age, sex, residence, exposure to culting and puncturing tools and blood transfusion. Multivariate analysis revealed age to be the best predictor of the carrer rate of hepatius $B$ virus.

L'infection par le virus de l'hépatite $B$ chez les Yéménites a Sanaa : tableau et facteurs de risque RESUME Une étude séro-épidémiologique transversale a été réalișée sur 2652 personnes (âge compris entre 1 mois et 95 ans ; médiane 23 ans) qui se sont présentées au laboratoire de santé central de Sanaa suite à une campagne de lutte contre le virus de l'hépatite $B$. Le dépistage a été réalisé par hémagglutination passive inversée. La spécificité des échantillons positifs a été déterminée par dosage immunoenzymologique. Sur 2321 participants. $7.4 \%$ ètaient porteurs de l'antigène de surface de l'hépatite $B$. Les facteurs de risque déterminés par l'analyse bivariée était l'ảge, le sexe, la résidence. l'exposition à des instruments coupants ou perforants et la transfusion sanguine. L'analyse multivariée a révélé que l'ảge était le meilleur élément prédictif du taux de portage du virus de l'hépatite B.

'Department of Medical Laboratory Science, Al-Hudaydah University, Al-Hudaydah, Republic of Yemen.

${ }^{2}$ Faculty of Medicine and Health Sciences, University of Sana'a, Sana'a, Republic of Yemen.

Received: 04101100; accepted: 12/09100

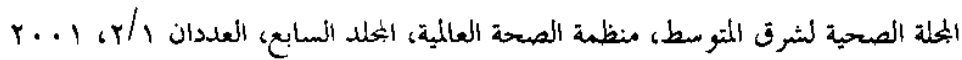




\section{Introduction}

Worldwide, an cstimatcd 350 million chronic carriers of hepatitis $B$ virus (HBV) are at high risk of liver cirrhosis and cancer [l]. Chronic carriers of HBV constitute more than $10 \%$ of the populations of tropical Africa and East Asia [2].

The Ministry of Public Health in the Republic of Yemen ranks HBV infection 12th on its list of major public health problems [3]. In two separate studies on non-probability samples of pregnant women in Sana'a, carrier rates of hepatitis B surface antigen (HBsAg) of $11.5 \%$ and $15.4 \%$ were reported [4,5]. Other studies, in 1990 [6] and in 1993 [7], revealed carrier rates of $12.7 \%$ and $18.5 \%$ respectively.

While the mode of transmission is well known, patterns of HBV infection and associated risk factors in the Yemeni population have not been adequately investigated. Previous studies in the Republic of Yemen indicate age to be positively correlated with acquiring the infection [4-6]. A previous history of blood transfusion and hospitalization [4], or blood transfusion and abortion [5] are also considered risk factors.

We aimed to describe the pattern of HBV infection, estimate prevalence, investigate possible risk factors and provide a detailed description of carrier characteristics in an adequate sample size, with relatively low bias. The study also investigated environmental, occupational, social and behavioural factors in relation to infection rates, in order to provide baseline information for setting priorities on immunization and for future studies.

\section{Methods}

A total of 2652 individuals (age range: 1 month-95 years; median 23 years) who presented at Sana'a Central Health Laboratory in response to a campaign to control HBV infection were recruited into the study. They were divided into two groups. Group $1(n=2321)$ was used to look at IIBV prevalence and patterns of infection. This group included 1600 people (800 who presented individually and 800 who were members of 165 families) and 721 blood donors. Excluded from Group 1 were those who had been previously screened for HBsAg. Group 2, made up of 331 individuals who had been tested previously, was used to study risk factors.

The screening was carried out by reverse passive haemagglutination testing (SERODIA-HBs). The specificity of this method in positive samples was reexamined using an enzyme immunoassay (PATHOZYME-HBsAg, Abbott Laboratories). All the participants were investigated for social (marital status), behavioural (sharing sharp instruments), cultural (educational status) and occupational associations, using questionnaires completed by the investigators. Data were collected over a 4-month period (June-September, 1999). Dala were anlalysed using SPSS, version 9.1 .

\section{Results}

Of the total number of participants tested, 221 were HBsAg-positive. Tests performed on the 2321 sera samples revealed an HBsAg prevalence of 7.4\%. Among the individuals who presented with their families, the prevalence was $3.4 \%$ (average family size 4.86 persons). A prevalence rate of $7,1 \%$ was found among the 721 blood donors. Of those presenting individually $(n=$ 800 ), the prevalence rate was $7.6 \%$.

HBsAg carricr rates among different age groups are shown in Figure 1. Only in 


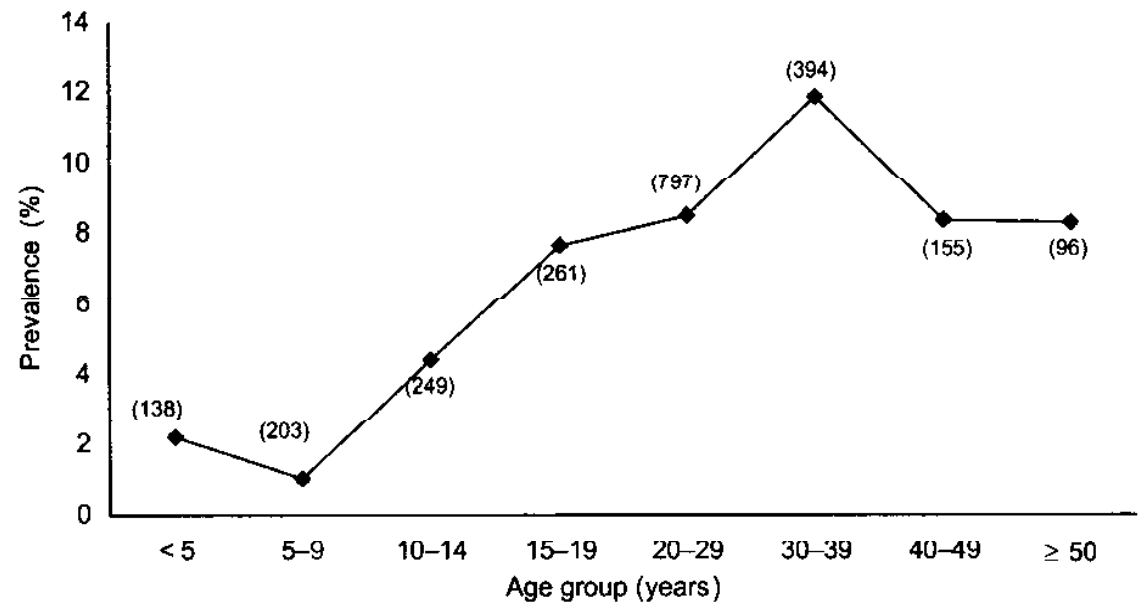

Figure 1 Hepatitis B surface antigen carrier rate among different age groups of the 2321 participants in Group 1, Sana'a, 1999. Figures in brackets are the number of participants in each age group. The total number examined was 2293 as 28 participants did not disclose their agas.

16 out of the 165 families tested did at least one family member test positive. Among the families with positive cases: in 4 families the mother plus one or more other family member tested positive; in 4 families, only the father was positive; in 3 families, the father plus at least one other family member were positive; and in 6 families, neither parent was positive, only one or more sibling. Among those with a previous history of jaundice $(n=149)$, the $\mathrm{HBsAg}$ carrier rate was $5.4 \%$, compared to $7.5 \%$ among those without any previous history $(n=2126)$. This may indicate a high frequency of other types of hepatitis infection. Other factors studied in relation to HBsAg carrier rate among the 2321 individuals in Group 1 are shown in Table 1.

Bivariate analysis for the 2652 total sample showed a positive association between carrier rate and male sex, older age, nural residence, past history of shared use of sharp instruments and blood transfusion. Marital status and direct contact with a jaundiced individual were not related (Table 2).

Multiple regression was used to determine the extent to which age was a predictor of carrier rate, adjusting for those factors found positive under bivariate analysis. Using a gold standard and backward elimination, residence, blood transfusion and shared use of sharp devices were excluded. Only age and sex continued to be significant. Further, the odds ratio for age was comparable in the crude model and gold standard (1.0221 and 1.0177 respectively). Age alone was, therefore, considered the best predictor of infection, according to the following equation:

Logit (rate of infection) $=-2.932+$ $0.0218 \times$ age (continuous)

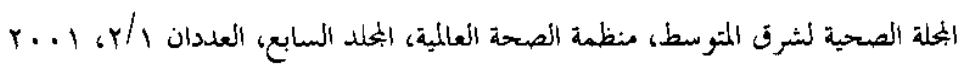


Table 1 Hepatitis B surface antigen (HBsAg) carrier rate according to the characteristics of the 2321 participants in Group 1, Sana'a city, 1999

\begin{tabular}{|c|c|c|c|c|c|c|c|}
\hline \multirow[t]{2}{*}{ Characteristic } & \multicolumn{2}{|c|}{ Positive } & \multicolumn{2}{|c|}{ Negative } & \multirow[t]{2}{*}{ Total no. } & \multirow[t]{2}{*}{$x^{2}$} & \multirow[t]{2}{*}{ P.value } \\
\hline & No. & $\%$ & No. & $\%$ & & & \\
\hline Sex & & & & & & 11.92 & 0.000 \\
\hline Male & 139 & 8.7 & 1465 & 91.3 & 1604 & & \\
\hline Female & 33 & 4.6 & 684 & 95.4 & 717 & & \\
\hline Res/dence & & & & & & 8.83 & 0.005 \\
\hline Urban & 115 & 6.8 & 1582 & 93.2 & 1697 & & \\
\hline Rural & 19 & 13.6 & 121 & 86.4 & 140 & & \\
\hline Oocupotion' & & & & & & 12.04 & 0.081 \\
\hline Student & 24 & 7.9 & 281 & 92.1 & 305 & & \\
\hline Housewife & 18 & 6.5 & 257 & 93.5 & 275 & & \\
\hline Manual worker & 50 & 13.2 & 328 & 86.8 & 378 & & \\
\hline Office employee & 22 & 8.2 & 247 & 91.8 & 269 & & \\
\hline Teacher & 9 & 11.4 & 70 & 88.6 & 79 & & \\
\hline $\begin{array}{l}\text { Soldier } \\
\text { Self-employed }\end{array}$ & 13 & 8.4 & 141 & $9 \uparrow .6$ & 154 & & \\
\hline business man & 2 & 7.1 & 26 & 92.9 & 28 & & \\
\hline Medical staff & 3 & 21.4 & 11 & 78.6 & 14 & & \\
\hline Marital status. & & & & & & 0.09 & 0.788 \\
\hline Ever married & 102 & 9.4 & 984 & 90.6 & 1086 & & \\
\hline Never married & 39 & 8.8 & 404 & 91.2 & 443 & & \\
\hline Literacyd & & & & & & 5.13 & 0.163 \\
\hline Illiterate & 21 & 8.9 & 216 & 91.1 & 237 & & \\
\hline Read and write & 25 & 11.5 & 192 & 88.5 & 217 & & \\
\hline School level & 86 & 7.1 & 1119 & 92.9 & 1205 & & \\
\hline Higher studies & 37 & 8.1 & 421 & 91.9 & 458 & & \\
\hline Family status & & & & & & 28.98 & 0.000 \\
\hline Family member & 27 & 3.4 & 773 & 96.6 & 800 & & \\
\hline Single & 145 & 9.5 & 1376 & 90.5 & 1521 & & \\
\hline
\end{tabular}

${ }^{a}$ Residence: 484 subjects were excluded; 253 trom ofher governorates and 230 did not answer. 'Occupation: 819 subjects were excluded; $794<19$ years and 25 did not answer.

Marital status: 792 were excluded; $777<79$ years and 15 aid not answer.

'Literacy: 204 were excluded; $178<$ age of marriage and 26 did not answer.

\section{Discussion}

Our study revealed a lower carrier rate in families $(3.4 \%)$ than reported from Sand"a $(11.5 \%$ to $18.5 \%)[4-6]$, Taiz $[7]$ and other areas [6]. Also, unlike the earlier findings, our result is lower than that reported from
Saudi Arabia (6.7\%), the Republic of Yemen's northern neighbour.

The HBsAg carrier rate found in our study suggests that Sana'a city can be classified as an intermediate, rather than high, infection area. The relatively low rate of infection $(3.5 \%)$ in the $<15$ years age group, 
Table 2 Risk factors associated with hepatitis B surface antigen (HBsAg) carrier status in the 2652 participants (Groups 1 and 2), Sana'a city, 1999

\begin{tabular}{|c|c|c|c|c|c|c|c|}
\hline \multirow[t]{2}{*}{ Risk factor } & \multicolumn{2}{|c|}{ Positive } & \multicolumn{2}{|c|}{ Negative } & \multirow[t]{2}{*}{ Total no. } & \multirow[t]{2}{*}{$x^{2}$} & \multirow[t]{2}{*}{$P$-value } \\
\hline & No. & $\%$ & No. & $\%$ & & & \\
\hline Sex & & & & & & 13.66 & 0.000 \\
\hline Male & 179 & 9.6 & 1680 & 90.4 & 1859 & & \\
\hline Female & 42 & 5.3 & 751 & 94.7 & 793 & & \\
\hline Residence ${ }^{a}$ & & & & & & 11.12 & 0.002 \\
\hline Rural & 24 & 15.1 & 135 & 84.9 & 159 & & \\
\hline Urban & 145 & 7.6 & 1771 & 92.4 & 1916 & & \\
\hline Age (years) & & & & & & 20.43 & 0.000 \\
\hline$<15$ & 23 & 3.5 & 641 & 96.5 & 664 & & \\
\hline$\geq 15$ & 198 & 10.1 & 1759 & 89.9 & 1957 & & \\
\hline Post history & & & & & & 6.18 & 0.010 \\
\hline Exposed & 49 & 11.4 & 382 & 88.6 & 431 & & \\
\hline Not exposed & 166 & 7.7 & 1979 & 92.3 & 2145 & & \\
\hline Rlond transfusiond & & & & & & 6.99 & $n 010$ \\
\hline Yes & 18 & 15.0 & 102 & 85.0 & 120 & & \\
\hline No & 199 & 8.1 & 2250 & 91.9 & 2449 & & \\
\hline Direct contact & & & & & & 5.26 & 0.070 \\
\hline Yes & 27 & 12.6 & 187 & 87.4 & 214 & & \\
\hline No & 188 & 8.1 & 2133 & 91.9 & 2321 & & \\
\hline Marital status & & & & & & 1.79 & 0.104 \\
\hline Ever married & 135 & 10.8 & 1115 & 89.2 & 1250 & & \\
\hline Never married & 45 & 8.7 & 473 & 91.3 & 518 & & \\
\hline
\end{tabular}

Residence: 577 were excluded: 306 from other governorates and 271 did not answer.

'Age: 31 did not answer.

cPast history: 76 did not answer.

alood transfusion: 83 did not answer.

Direct contact: 117 were excluded; 16 did not know and 101 did not answer.

Marital status: 884 were excluded; $862<19$ years and 22 did not answer.

compared to $10.1 \%$ in the $\geq 15$ years age group, indicates that most infection occurred as a result of lifestyle and behavioural factors rather than environmental or host factors. The rate of $2.2 \%$ in early age ( $<5$ years) points to probable vertical transmission and/or early parenteral exposure (circumcision or ear puncture). The lowest prevalence rate $(1.0 \%$ at age 5 years) suggests the elimination of antigens from the system. The rate increased steadily with increased age, until it peaked at $11.9 \%$ (in the age group $30-39$ years) and then reverted to rates comparable with those in the 20-year-old age group.

Our study also revealed the years of greatest incidence to be 10-19 years and 30-39 years. From this, we can infer that immunization at ages 9,14 and 29 years could substantially reduce the carrier rate.

The high rate found among teachers $(11.4 \%, n=79)$ and also among family members whose mothers were infected supports the view that being in close contact with carriers increases the risk of infection. Our finding that rural residents had

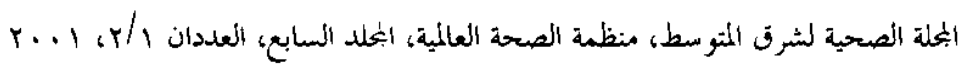


a higher carrier rate $(15.1 \%)$ than urban residents $(7.6 \%)$ is contrary to Al-Faleh's findings [8]. The rural-urban difference in the present study was eliminated when backward multiple regression was applied, suggesting that only older, male villagers tend to visit the cities.

When we looked at the best predictors for occurrence of infection, age and sex continued to be significant, while residence, sharing of sharp instruments and blood transfusion were eliminated. This would seem logical, as with ageing, bleeding experiences increase. Thus, age can substitute for other predictors, a finding compatible with those of Al-Shamahy, Abdel Raheem and Scott [4-6].

\section{References}

1. No scientific justification to suspend hepatitis B immunization. Geneva, World Health Organization, 1998 (Press release WHO 67).

2. Tiollais $P$, Purcel $C$, Dejean $A$. The hepatitis B virus. Nature, 1985, 317:489-95.

3. Vomoni Ministry of Public Health 5-Vear Plan, 1987-1991. Sana'a, Ministry of Public Health, 1987:23-4.

4. N Shamahy HA. Provalonco of hopatitis B surface antigen and risk factors of HBV infection in healthy mothers in Sana'a. Yemen medical joumal, 1999, 3:76-9.

5. Abdel Raheem SM et al. Hepatitis B infection in Sana'a city, Republic of Yemen: prevalence among pregnant women and maternofoetal transmission Journal of the Egyptian Public Health Association, 1991, 66:491-503.

6. Scott DA et al. A seroepidemiological survey of hepatitis in the Yemen Arab Republic. Transactions of the Royal Society of Tropical Medicine and Hygiene, 1990, 64:288-91.

7. El-Guneid et al. Prevalence of hepatitis $B, C$ and $D$ virus markers in Yemeni pationte with ohronic liver disease. Joumol of medical virology, 1993, 40:330-3.

8. Al-Faleh FZ et al. Seroepidemiology of hopatitis $B$ virus infection in Saudi Arabian children: a baseline survey for mass vaccination against hepatitis $B$. Journal of infection, 1992, 24:197-206. 